\title{
Multi-level governance and the role of the regions in the European Union: conceptual challenges and practical applications
}

\author{
Karolina Borońska-Hryniewiecka \\ Ph.D. \\ University of Wrocław
}

\begin{abstract}
Summary: I. Introduction. - II. The conceptual challenge of multilevel governance in the context of regional participation in European policy-making. 1. Different ways to think about 'governance'. 2. When do we talk about multi-level governance: between neofunctionalism and intergovernmentalism. 3. EU policy-making as an example of multi-level governance. 4. What role for the regions ?-III. How to 'measure' multilevel governance ? 1 . The case of policy control: subsidiarity monitoring. 2. Consultation and impact assessment as instruments of MLG. 3. Regional involvement in cohesion policy: the case of EGTC.-IV. Multi-level governance and regional empowerment. $-\mathrm{V}$. Conclusions: Where do we go from here?
\end{abstract}

Resumen: Este artículo ofrece una aproximación conceptual de la gobernanza multi-nivel (GMN) en la Unión Europea y su aplicación como herramienta analítica en el estudio de la participación de los entes subestatales en el proceso de construcción europea. Con este fin, el artículo proporciona una serie de indicadores para «medir» la GMN y evalúa ciertos desarrollos institucionales hacia GMN, al tiempo que pretende determinar las implicaciones de la GMN en el poder regional. El estudio llega a la conclusión de que a pesar de la existencia de estímulos e incentivos relevantes para promover una mayor cooperación, partenariado e inclusión, el proyecto de la gobernanza multi-nivel europea no se ha institucionalizado todavía. Para valorar en términos cualitativos la GMN, este trabajo propone tomar en cuenta la amplia gama de indicadores de naturaleza normativa, sistémica y procedimental presentes en un específico contexto doméstico, o aplicables a una determinada política, para ponerlos a prueba en el marco de los instrumentos actualmente operativos. En este aspecto, se echan en falta estudios sistemáticos y comparados, especialmente en el ámbito de las políticas europeas con importante impacto territorial.

Palabras clave: proceso de decisión política en la Unión Europea, gobernanza multinivel, regiones, poder regional.

Abstract: The aim of this article is to provide a framework for analysis of the concept of multi-level governance (MLG) in the European Union and its applica- 
tion as an analytical tool in the study of subnational participation in European policy-making. In doing so, it proposes a range of indicators for measuring $M L G$, evaluates certain institutional developments towards MLG as well as determines the implications of MLG for regional empowerment. The article concludes that in spite of the existence of stimuli and incentives for evolution towards cooperation, partnership and inclusion, we can still observe a low degree of institutionalization of $M L G$ in the EU. In order to determine the 'quality' of MLG the study proposes to take into account a wide range of normative, systemic and procedural indicators present in a specific domestic context or applicable for a given policy area and 'test' them against the real-life mechanisms in operation. Systematic and comparative studies on the effectiveness of MLG are needed especially in the fields of policies with high territorial impact.

Keywords: European policy-making, multi-level governance, regions, regional empowerment

\section{Introduction}

The process of European integration has generated significant changes in the ways European policies are designed and implemented. The European Union (EU) has refashioned the European balance of power by shifting the considerable number of competences from central states to the supranational level. Inevitably, this shift has directly affected the subnational level. For the regions with legislative power, the initial process of European integration has resulted in a 'double centralizing effect'. On the one hand, the EU has gradually taken over legislation in policy areas of subnational competence such as agriculture, trade, economic development, transport or environment. On the other, by accident or by design, the states have gained the possibility to intervene in the subnational sphere of competence by the specificity of the EU decisionmaking process.

Over the last three decades we can observe a gradual redistribution of authority among several tiers of government in the EU which results in opening up new areas for regional participation in European affairs. The activity of regional offices in Brussels, growing role of the Committee of the Regions or involvement of regional authorities in designing EU cohesion policy have given the regions new channels of participation in EU everyday life. Institutional reforms have been accompanied by changes in European decision-making culture reflecting the multi-level properties of EU system. In view of the above, not only scholars but also policy-makers have increasingly started to apply the notion of 'multi-level governance' (MLG) 
to conceptualize the emerging framework of EU polity and the relationships among the different tiers of government. ${ }^{1}$

The aim of this article is to provide a framework for analysis of the concept of multi-level governance in the EU and its application as an analytical tool in the study of subnational participation in EU policy-making. In doing so, it proposes a range of indicators for measuring MLG, evaluates certain institutional developments towards MLG as well as determines the implications of MLG for regional empowerment. The article concludes that in spite of the existence of stimuli and incentives for evolution towards cooperation, partnership and inclusion, we can still observe low degree of institutionalization of MLG in the EU. At the same time more systematic and comparative studies on the effectiveness of MLG are needed especially in the fields of policies with high territorial impact.

\section{The conceptual challenge of multi-level governance in the context of regional participation in European policy-making}

\section{Different ways to think about 'governance'}

At this point, in order to elucidate the concept of MLG, it seems reasonable to establish what the very concept of 'governance' means and what are its principal characteristics.

From the institutional perspective, governance means influencing the structures through which different actors (citizens, civil servants, interest groups, etc.) participate in politics ${ }^{2}$. More specifically, governance is about

${ }^{1}$ BACHE, I., Europeanization and Multi-level governance, cohesion policy in the European Union, Rowman and Littlefield Publishers, Plymouth 2008; KEATING, M., Regions and regionalism in Europe, Edward Elgar Cheltenham 2005; MORATA, F., Gobernanza multinivel en la Union Europea, Tirant lo Blanch, Valencia, 2004; SCHMITTER, P., Neo-functionalism, in WIENER, A., DIEZ, P. (eds), European Integration Theory, Oxford University Press, Oxford 2004; BÖRZEL, T., States and regions in the European Union, Cambridge University Press 2002; HOOGHE, L., MARKS, G., Multi-level Governance and European Integration, Rowman and Littlefield, Oxford, 2001; PIERRE, J., PETERS, B.G., «Developments in intergovernmental relations: towards multi-level governance» in Policy \& Politics, vol 29 no 2: 2001; SCHARPF, F.W., Notes Towards a Theory of Multilevel Governing in Europe, MPIfG Discussion Paper 2000/5: http://www.mpi-fg-koeln.mpg.de/pu/mpifg_dp/ dp00-5.pdf (accessed 08 August 2010 EISING, R., KOHLER- KOCH, B., The transformation of governance in the European Union, Routledge, London 1999; WARELEIGH, A., The Committee of the Regions: Institutionalising Multi-level Governance?, Kogan Page Limited, London 1999.

2 MARCH, J.G., OLSEN, J.P., Democratic Governance, The Free Press, New York, 1995, p. 6. 
setting, exercising and executing rules. The essence of governance just like that of government is to reach binding decisions, however governance does neither rest on a constitutionally defined legitimacy, nor on political majority, but on constant renegotiations of shared interests and exchange of resources among the involved stakeholders ${ }^{3}$.

It needs to be made clear: there is no one way of thinking about governance. In majority of definitions the term governance refers to sustaining coordination and coherence among a wide variety of actors with different purposes and objectives such as political actors and institutions, corporate interests, civil society and transnational organizations ${ }^{4}$. The most important features of this system are lack of clear-cut hierarchy, existence of highlyorganized constituencies representing multitude of interests and a significant degree of negotiation and cooperation between them.

Rhodes ${ }^{5}$ distinguishes seven ways of defining 'governance' depending on the area of scientific interest, i.e.: corporate governance in business corporations; New Public Management in public sector; 'good governance' of international agencies such as the World Bank; New Political Economy in the relations between civil society, the state and the market; governance as international interdependence; socio-cybernetic system, and finally network governance. In all these conceptualizations 'governance' becomes all-embracing concept capable of conveying diverse meanings not covered by the traditional term 'government'.

The last three of the aforementioned definitions fit within the scope of the research on the role of subnational government in the process of European policy-making. In this context, the first of Rhodes' conceptualizations (i.e. governance as international interdependence) argues that international interdependencies and pressures erode the authority of the state which delegates power upwards to supranational level and downwards to sub-national agencies. In this situation, the nation state's capacities for governance are weakened, but it is still envisaged as a source of constitutional ordering providing minimum standards in a world of interlocking networks of public powers ${ }^{6}$. The socio-cybernetic approach also highlights the limits to 'governing' by a central actor (the state), claiming that there is no longer a single sovereign authority, but a great variety of interdependent social-political and economic actors with blurred boundaries between their public and

${ }^{3}$ EISING, R., KOHLER- KOCH, B., op. cit., note 1.

${ }^{4}$ PIERRE, J., Debating Governance, Oxford University Press, 2000.

5 RHODES, R., «Governance and Public Administration», in (ed.) PIERRE, J. op. cit., note 4, p. 55.

${ }^{6}$ HIRST, P., THOMPSON G., «Globalisation and the future of the Nation State» in Economy and Society, No. 24, 1995, pp. 408-42. 
private memberships as well as new forms of action, intervention and control $^{7}$. In this sense, majority of authors use the concept of governance as a synonym of process of governing through certain specialized institutions in absence of central authority ${ }^{8}$. The core idea of governance is that the traditional role of the state has changed from authoritative allocation 'from above' to the role of an 'activator' of a process of intermediation aimed at coordinating political actions of actors in an interdependent system ${ }^{9}$.

Consequently, network governance approach points to a growing role of self-organizing networks as a form of social coordination caused by the need to exchange resources and negotiate shared purposes. As Izdebski notes, networks constitute important point of reference in elaborating governance ${ }^{10}$. It is tought that one of the roles of 'good public governance' is network management - creation of suitable conditions and facilitation of interactive processes within networks in order to solve problems of inadequate representation and articulation of interests ${ }^{11}$. Networks can vary considerably with regard to their degree of cohesion, ranging from coherent policy 'communities' to loose 'single-issue coalitions' ${ }^{12}$. Analysing the changing institutional architecture of the EU it is being observed how it acquires network character ${ }^{13}$, where hierarchical authority relations are no longer the dominant structural feature (e.g. networks of member state representatives, networks linking the national and the European levels of decision-making, networks linking subnational authorities with supranational level or involving public and private actors across policy sectors and political levels).

7 RHODES, R., op. cit., note 4, p. 58.

${ }^{8}$ KOHLER-KOCH, B., EISING, R., op. cit., note 1; PIERRE, J. Debating governance, Oxford University Press; KOHLER-KOCH, B., «Interactive governance: Regions in the network of European politics», European Union Studies Association (EUSA) > Biennial Conference, May 29-June 1, Seattle, WA.1997.

9 KOHLER-KOCH, B., EISING, R., op. cit., note 1.

${ }^{10}$ IZDEBSKI, H., «Od administracji do public governance» in HAUSNER, J. (ed.) Zarzadzanie Publiczne UEK, Kraków, 2007.

11 KLIJN, E.H., KOPPENJAN J.F.M., «Public Management and Policy Networks. Foundations of a Network Approach to Governance» in Public Management, vol. 2.

12 RHODES, R.A.W., Understanding Governance. Policy Networks, Governance, Reflexitivity and Accountablity, Open University Press, Buckingham 1997.

13 KOHLER-KOCH, B., «European governance and system integration» in European governance papers (EURGOV) No. C-05-01, 2005: http://www.connex-network.org/eurogov/ pdf/egp-connex-C-05-01 (Accessed 10 December 2009); SROKA, J., Polityka organizacji pracodawców i przedsiębiorców, Wydawnictwo Uniwersytetu Wrocławskiego, Wrocław, 2004; PETERSON, J., «Policy Networks» in IHS Political Science Series, No. 90/2003: www.aei.pitt. edu/764/01/pw_90.pdf (accessed 3 March 2009); SBRAGIA, A. M., «The European Union as Coxwain: Governance by Steering» in (Ed.) PIERRE, J., Debating governance, Oxford University Press, 2000; HIX, S., «The study of the European Union II: The 'New Governance' Agenda and its Rival»in Journal of European Public Policy 5:38-65, 1998. 
2. When do we talk about multi-level governance: between neofunctionalism and intergovernmentalism

MLG - a concept that spans by now at least seventeen years - has come to light as a result of the study of developments in the structural policy of the European Community, the partnership principle in particular, conducted by Gary Marks ${ }^{14}$. In an early article on this notion, Marks defined MLG as $a$ system of continuous negotiation among nested governments at several territorial tiers ${ }^{15}$. In developing this definition he drew on analysis of domestic politics, especially policy-networks approach in describing how within the MLG supranational, national, regional and local governments are enmeshed in territorially overreaching policy networks ${ }^{16}$. Marks sought to use the concept of MLG not just to describe a peculiar type of policy-making (i.e. cohesion policy), but processes transforming political and social mobilization more generally. He has drawn attention to the capacity of non-central state authorities to contribute to EU policy-making by crossing the domestic-foreign gate and challenging the gatekeeping capacity of the central state $^{17}$.

Before Marks introduced his concept of MLG, the field of EU studies had been dominated by the discourse between two major schools of European integration, namely: neo-functionalists and intergovernmentalists (or supranationalists), who argued not only about the origins of the European integration but also about the nature of the EU (See Table 1).

While the neofunctionalists argued that central governments shift their allegiances away from national settings towards new supranational centre, whose institutions create a new political community, superimposed over the existing ones ${ }^{18}$ liberal intergovernmentalists held that the control of state executives at the agenda setting stage of EU policy-making has been reinforced and confers on them the 'gate keeping' and institution-building power ${ }^{19}$. Supporters of the former theory argue that European integration

${ }^{14}$ MARKS, G., «Structural Policy and Multilevel governance in the EC», in CAFRUNY, A.W., ROSENTHAL, G.C. (ed.), The state of the European Community: The Maastricht debates and beyond, vol 2, Lynne Rienner Publisher: Baoulder, 1993, pp. 391-411.

15 MARKS, G., op. cit., note 14, p. 392.

16 Ibidem, p. 402.

17 SCHARPF, F.W., SCHMITTER, P. C., MARKS, G., Governance in the European Union, Thousand Oaks, London 1996.

18 HAAS, E.B., The Uniting Europe: Political, Social and Economical Forces: 19501957, Stevens and Sons Limited, London, 1958, p. 16.

19 TAYLOR, P., «The European Community and the State: Assumptions, Theories and Propositions» in Review of International Studies 17:109-125, 1991; MORAVCSIK, J., The choice for Europe: Social purpose and state power from Messina to Maastricht, New York: Cornel University Press, 3, 4.2.1, 5.3, 1998. 
Table 1

Impact of European integration on power relations in the EU: summary of arguments

\begin{tabular}{|c|c|c|}
\hline $\begin{array}{l}\text { European integration } \\
\text { theories }\end{array}$ & $\begin{array}{c}\text { Nature of } \\
\text { decision-making process }\end{array}$ & $\begin{array}{l}\text { Position } \\
\text { of the state }\end{array}$ \\
\hline Intergovernmentalism & $\begin{array}{l}\text { Voluntary bargaining } \\
\text { between national } \\
\text { executives }\end{array}$ & Reinforced \\
\hline Supranationalism & $\begin{array}{l}\text { Decisional power } \\
\text { gradually overtaken } \\
\text { by supranational } \\
\text { constituencies, as a result } \\
\text { of voluntary delegation }\end{array}$ & Disempowered \\
\hline Multi-level governance & $\begin{array}{l}\text { Decisional power shared } \\
\text { among governing } \\
\text { institutions at different } \\
\text { territorial levels and } \\
\text { influenced by non-state } \\
\text { actors }\end{array}$ & Increasingly interrelated \\
\hline
\end{tabular}

Own elaboration based on: HOOGHE, L. and MARKS, G. Multi-level Governance and European Integration, Rowman and Littlefield, Oxford 2001.

is a process leading to a creation of new supranational political community to which authority would be delegated by governments of Member States. Consequently, state elected officials, interest groups and large commercial interests within states would transfer their allegiances away from national institutions towards the supranational bodies because they would, in theory, come to realize that these are better equipped to pursue their material interests than the pre-existing national institutions. To this, intergovernmentalists respond with their vision of European intergovernmental regime, in which national executives remain the ultimate responsible for the development of public policies, willing to limit their sovereignty only to the extent which they consider beneficial for their states. In this sense, Moravscik argued that (European) institutions, once created, do not take on a life of their own, but are always subservient to the states that only cooperate and negotiate with other states if they have similar interests $^{20}$.

${ }^{20}$ MORAVSCIK, J., op. cit., note 19, pp. 474-482. 
Fluctuations in the process of European integration periodically favored one of the theories over the other ${ }^{21}$. Yet, while the debate between intergovernmentalists and supranationalists attempted to give explanation about the driving forces of European integration, it has not contributed to exploring more post-ontological questions of how the EU affects the agency and structure of different actors ${ }^{22}$. Such perception of affairs and the need to highlight the importance of what is actually going on with the main actors involved in the process of European integration have led to introduction of a third paradigm, that of MLG, in which the EU ceases being dependent variable, a problem to be studied, and becomes an independent variable influencing other institutions and decision-making processes ${ }^{23}$.

As mentioned before, the concept of MLG was first applied in the field of cohesion policy, as it was in this field that multi-level mobilization dynamics and decision-making patterns were most apparent. With time however, its logic has been applied to different policy realms as well as embraced different institutional settings. Schmitter has extended MLG beyond intergovernmental relations - to the private sector - seeing it as an arrangement for making binding decisions (...) at different levels of territorial aggregation in more-or-less continuous negotiation/deliberation/implementation, which does not assign exclusive policy competence or assert a stable hierarchy of political authority to any of these levels ${ }^{24}$. This understanding of MLG distinguishes it from federalism limited to intergovernmental relations, which does not assume elasticity, uncertainty and fluidity as typical organizing principles. Piattoni ${ }^{25}$ sees MLG as a concept moving across and connecting different political planes. These planes are occupied by governments, institutions of intergovernmental nature (EU) as well as a wide range of non-governmental agents whose participation in the political, economic and social life of the EU as well as in the global sphere, is formally recognized.

Of course, MLG is not the only concept describing the institutional developments in the EU. As Hooghe and Marks point out ${ }^{26}$ terms such as

21 See METTE KJAER, A., Rzqdzenie, Sic! s.c., Warszawa, 2009, pp. 118-126.

${ }^{22}$ ROSAMUND, B., Theories of European Integration, Macmillan, London, 1999; HIX, S., op. cit., note 10; WEAVER, R.K., ROCKMAN, B.A., Do Institutions Matter? Government Capabilities in the United States and Abroad, Brookings, Washington DC, 1993.

${ }^{23}$ See: METTE KJAER, A., op. cit., note 21, pp. 118-126.

${ }^{24}$ SCHMITTER, P., op. cit., note 1, p. 49.

25 PIATTONI, S., 2009 Multi-level governance in the EU. Does it work?, Paper for a conference in Honour of Suzanne Berger : http://www.princeton.edu/ smeunier/Piattoni (accessed 11 October 2010).

${ }^{26}$ HOOGHE, L., MARKS. G., «Unravelling the central state, but how? Types of multilevel governance» in Political Science Series 87, Institute for Advanced Studies, Vienna, 2003. 
multi-tiered governance, polycentric governance, consortio, condominio or FOCJ (functional, overlapping competing jurisdictions) have been employed and all share the observation of dispersion of authority vertically, to actors located at others territorial levels, and horizontally, to non-state actors. Yet, if MLG were just a catchy descriptor of independent transformations, it would not serve much as a framework to study the precise relationships between activities of the different levels of authority and would tell us nothing more than what each component word of the notion of MLG independently conveys, i.e.: governing at multiple levels ${ }^{27}$.

First of all, MLG offers an analytical tool to study the increasing number and complicated character of the relations among various institutional and political actors both in vertical and horizontal dimension. It is a multi-dimensional concept itself because it moves across and connects different analytical spaces such as politics, policy and polity as well as different territorial (or jurisdictional) levels such as supranational, national and subnational. MLG is interesting precisely because of its transversal ${ }^{28}$ and dynamic nature.

Secondly, MLG provides a normative model aimed at improving the efficiency and effectiveness of the decision-making process in a complex and interdependent system of the EU (output legitimacy of MLG). At the same time, it does not neglect the question about the democratic deficit of the EU inspiring EU policy-makers to seek ways for an enhanced and effective inclusion of new actors into the decision-making process and administering of various fields of European policies. The questions about the efficacy of intergovernmental cooperation as well as the instruments for collective decision-making engaging subnational and national authorities are at the centre of MLG analysis. MLG as a normative model provides certain conditions serving to improve the quality of the European governance.

In general, MLG theory makes four following claims (See Table 2): Firstly, decision-making powers are shared by actors at different levels rather than monopolized by state executives. Consequently, political power and institutional capability is less and less derived from formal constitutional powers accorded by the state but more from the capacity to wield and coordinate resources from public and private actors and interests ${ }^{29}$. From this the second claim is derived that power is shared among state and nonstate actors to the extent that the execution of public policies requires cooperation among multiple stakeholders. Thirdly, subnational actors operate in both national and supranational arenas, defying hierarchical orders. In this

\footnotetext{
27 PIATTONI, S., op. cit., note 25.

28 Cutting across domains and sectors

29 PETERS, B.G., PIERRE, J., op. cit., note 1.
} 
context, attention was drawn by Marks, et al. that the relevant levels of 'EU game' are not limited to the national and the supranational (as in Putnam's two-level game) but other levels (i.e. subnational and subregional) enter into play as well. It obviously implies that political arenas are interconnected and interdependent ${ }^{30}$ and that actors originally nested in regional or local arenas might successfully operate on national and supranational level in the pursuit of their interests. This claim leads to the final characteristic of MLG which is the growing role of self-organizing networks of public and private nature with vertically and horizontally overlapping memberships ${ }^{31}$.

The above requirements might be complemented with some other observations concerning the nature of MLG. For instance, within the framework of MLG, private actors might acquire public functions and on the contrary, public authorities might act as private groups. Such a blurring might be a strategy of mobilizing certain interests at levels which are not contemplated within the existing institutional order ${ }^{32}$. This dynamics are driven by the agency of actors who in the 'blurring' of these levels see the opportunity to pursue goals otherwise impossible to achieve (i.e. access to strategic decision-making bodies; possibility to represent interests otherwise unaddressed). As Piattoni points out, these dynamics might with time become legitimated and institutionalized creating this way new normative frameworks and rules of behavior.

Moreover, MLG in the EU transcends the traditional relation between territory, function and identity and enables non-hierarchical exchanges between institutions at the supranational, national, regional and local levels ${ }^{33}$. The 'non-hierarchical exchanges' imply that although we tend to think of the institutional levels of the aforementioned jurisdictions as vertically ordered, in reality institutional relationships do not have to operate through intermediary levels but can take place directly between, for example, the supranational and regional levels, thus bypassing the state level ${ }^{34}$. In this context, subna-

${ }^{30}$ HOOGHE, L., MARKS, G., op. cit., note 1; BACHE, I., Europeanization and Multilevel governance, cohesion policy in the European Union, Rowman and Littlefield Publishers, Plymouth, 2008.

31 PETERSON, J., «Policy Networks» in IHS Political Science Series, No. 90, 2003, http://aei.pitt.edu/764/01/pw_90.pdf (accessed 3 March 2009).

32 PIATTONI, S., op. cit., note 25.

33 PETERS, PIERRE, op . cit, note 1.

${ }^{34}$ PUCHALA, D., «Institutionalism, intergovernmentalism and European integration: a review article», in Journal of Common Market Studies, vol 37: 317-32. 1999; SCHARPF, F., The Problem Solving Capacity of Multi-Level Governance, Florence, European University Institute 1997; SCHARPF, et al. Governance in the European Union, London: Thousand Oaks, 1996; KOHLER-KOCH, B., «The Strength of Weakness: The Transformation of Governance in the EU», S. Gustavsson, L. Lewin (Eds.) The Future of the Nation-State, London. 1996, pp. $169-210$. 
tional governments are no longer constrained to dyadic political relations with national state actors, but have direct access to European institutions, mobilize directly in Brussels, interact with each other across national borders and form transnational platforms of cooperation. At first, political recognition of the regions was limited to EU structural policies, today however participation of the regions in the EU has been generally recognized, institutionalized in the European Treaties and extended to various involvements in policy-creation, such as for example monitoring of subsidiarity.

Table 2

Nature and functions of MLG

\begin{tabular}{|c|c|}
\hline Most important characteristics of MLG & Most important effects of MLG \\
\hline $\begin{array}{l}\text { 1. Decentralization and dispersion of } \\
\text { political power }\end{array}$ & $\begin{array}{l}\text { - Shift from power defined by rigid } \\
\text { division of competences (i.e. } \\
\text { constitutions, statutes) to power } \\
\text { based on resources, capacities and } \\
\text { strategies. } \\
\text { - Constant coordination, negotiation } \\
\text { and redefinition }\end{array}$ \\
\hline $\begin{array}{l}\text { 2. Participation of non-state actors and } \\
\text { civil society }\end{array}$ & - Depolitization of policy-making \\
\hline $\begin{array}{l}\text { 3. Subnational actors operating } \\
\text { simultaneously at national and } \\
\text { supranational level }\end{array}$ & $\begin{array}{l}\text { - Shift from hierarchical to non- } \\
\text { hierarchical structures }\end{array}$ \\
\hline $\begin{array}{l}\text { 4. Growing role of self-organizing } \\
\text { networks among actors and } \\
\text { institutions }\end{array}$ & $\begin{array}{l}\text { - Shift from dependence to inter- } \\
\text { dependence } \\
\text { - Limits to individual control }\end{array}$ \\
\hline
\end{tabular}

Source: Own elaboration based on Hooghe and Marks 2001, 2003; Eising and Kohler-Koch 1999

According to pioneers of MLG theory, Hooghe and Marks, MLG might be structured in a twofold way which they label correspondingly Type I and Type II MLG. Type I MLG describes general-purpose jurisdictions at limited number of levels which might be illustrated by international, national, regional and local tiers of authority carrying out similar sets of political and policy functions ${ }^{35}$. On the other hand, Type II MLG is composed of func-

35 HOOGHE, L., MARKS, G., op. cit., note 26, p. 7. 
tionally specialized jurisdictions of potentially huge number which operate at various territorial tiers. To repeat after Hooghe and Marks, these two types come and go as demands for governance changes ${ }^{36}$.The example of Type II jurisdictions might be transfrontier or transnational problem-driven jurisdictions composed of networks of regional leaders, parliamentary representatives, associations of local authorities, public and private entities or chambers of commerce cooperating on joint projects. Type II is generally embedded in Type I MLG and the analysis carried out in this thesis will account for both of them.

\section{EU policy-making as an example of multi-level governance}

Despite some variations across policy areas there is a broad consensus that the logic of EU governance is based on 'common decision-making' among actors integrated in a system steered by commonly agreed organizing principles. In its 2001 'White Paper on European Governance', the European Commission characterizes the EU as one based on multi-level governance in which each actor contributes in line with his or her capabilities or knowledge to the success of the overall exercise ${ }^{37}$. One of the most characteristic features of the EU is that it is governed without government, and it does not fit into any accepted category of government ${ }^{38}$. The legislative power of the EU is divided between the European Parliament and the governments of the member states in the Council of Ministers. Similarly, the executive power is shared by the Council and the Commission. In the present political architecture of the EU the individual state's sovereignty is diluted by the collective decision-making among national governments in the Council and its Working Groups, by the autonomous role of the multiple committees of the $\mathrm{EC}$, the rulings of the Court of Justice of the European Union (CJEU) and the European Central Bank as well as by the increasing necessity to include the stance of subnational governments and social actors in the creation and implementation of European policies. Moreover, in the view of its lack of own fiscal system and a potent budget, the EU depends on its capacity for self-regulation and internal cooperation on the allocation of resources, competences and rights between member states, regions, interests groups and other institutions. For this, the Commission and Parliament promote the principle of "part-

\footnotetext{
36 Ibidem, p. 8.

37 White Paper on Governance, European Commission (2001, 34-35).

38 SBRAGIA, A.M., «The European Community: A Balancing Act» in Publius, No. 27,
} 1993, p. 24. 
nership' to give the affected actors a say in framing and programming of EU policies ${ }^{39}$.

In reality, the process of European policy-making consists of three phases engaging a wide range of participants (See figure 1). The first stage is policy initiation marked by legislative initiative and agenda setting of the Commission shared with the Parliament and the Council of Ministers. Apart from EU institutions, this stage involves a multitude of interests groups and subnational actors who give input to the Commission's projects and influence the legislative initiatives well before they are made official ${ }^{40}$. Certain policy fields such as environment, agriculture, energy or waste policy require a broad, Europeanized approach, taking into account all possible local repercussions of the proposed solutions for the different stakeholders. To achieve it, the EC uses expertise from thousands of experts, lobbyists and interest groups located from local to supranational kevel. The next stage consists in legislative decision-making by voting in the Council of Ministers. Although dominated by national governments, this phase requires wide-reaching compromise where individual sovereignty has been diluted by the progressive extension of the qualified majority voting in the Council. ${ }^{41}$ Moreover, the Council of Ministers shares decision-making power with the supranational European Parliament in the so called 'co-decision procedure', which is now called the 'ordinary legislative procedure'. In fact, the Treaty of Lisbon has extended co-decision to forty new articles, which enhances the multi-level character of European policy-making as opposed to the state-centric model. Moreover, the Lisbon Treaty extended the obligatory consultation procedure in EU legislative process as a result of which the Commission and the Council are obliged to consult their legislative projects with the Committee of the Regions in a wide number of policy areas which affect regional and local competences. Once legislation is passed by the Council and the Parliament, it is the Commission's responsibility to ensure it is implemented. At this stage, as Hooghe and Marks note ${ }^{42}$, the MLG is most prominent. It is where the mechanism of 'comitology' comes into action. It refers to the committee system which oversees the delegated

39 See Mandelkern report, European Parliament, 2002, p. 34.

40 See BOROŃSKA-HRYNIEWIECKA, K., «Europeanization of non-state actors: Towards a framework of analysis», in (Ed.) ARMSTRONG, D., GILSON, J., et al., Civil Society and International Governance: The Role of Non-State Actors in Global and Regional Regulatory Frameworks, Oxon, Routledge, 2011.

${ }^{41}$ The Lisbon Treaty extends the qualified majority voting to 33 new articles. Together with the 63 articles where the qualified majority voting already applies, 96 articles are now under qualified majority voting. Yet, sensitive areas such as taxation, social security, foreign policy, common defense are still governed by unanimity.

${ }^{42}$ HOOGHE, L., MARKS. G., op. cit., nota 1. 
acts implemented by the EC. Comitology involves a wide range of nonstate and subnational actors from regional and local levels of jurisdictions who possess technical knowledge and necessary sensibility to monitor and manage the implementation of policies together with the Commission.

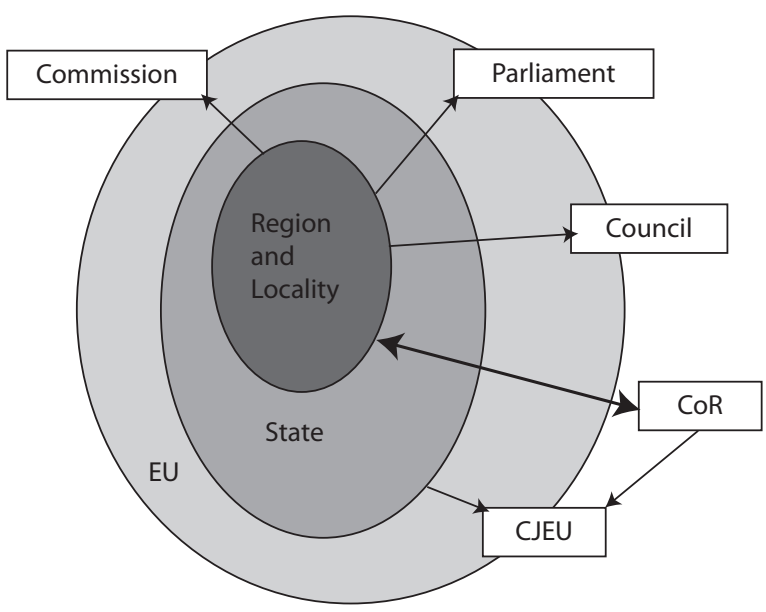

Source: Own elaboration.

\section{Figure 1}

MLG in the EU

Governing the EU involves bringing together the relevant state and non-state actors and building issue-specific constituencies. In this sense, MLG directly coincides with the network governance approach mentioned above. Within networks the level of political action ranges from supranational, through national, to subnational level of the member states. At each of these levels horizontal cooperation in issue specific networks takes place which serves to prepare joint positions on matters of common interest to be later negotiated vertically, with other levels of governance. Most of these networks have diverse memberships, extending from public to private, from European to sub-national or local, lack clear hierarchies and visible leaderships. At the supranational level, both state and non-state representatives participate in EC committees to elaborate early policy proposals in a way that the future legislative projects which the EC presents for acceptance to the Council and the Parliament take into account the interests of the affected parties. Holders of common interests tend to identify and 'bond' with each other in policy-networks in order to shift the European policy agenda 
in the direction of a policy change. Regional and local authories collaborate in transnational networks and through the CoR to prepare opinions on policy projects developed by the EC. In this context, few policy solutions are simply imposed by the state. As Eising and Kohler-Koch put it, European governance is about the structured ways and means in which the divergent preferences of interdependent actors are translated into policy choices 'to allocate values', so that the plurality of interests is transformed into coordinated action and the compliance of actors is achieved ${ }^{43}$.

The European Commission's 'White Paper on European Governance'44 lists the main organizing principles deciding about the 'goodness' of European governance such as: openness, participation, accountability, effectiveness and coherence. In this context, governance is perceived of as a postulated state of affairs which consolidates the legitimacy of European institutions bringing the EU closer to European citizens, making it more effective, inclusive and democratic. The White Paper proposes opening-up of policy-making process to involve more actors in shaping and delivering EU policy. Authors agree that the properties of EU system result in establishing new patterns of actor relations and create new decision-makings routines ${ }^{45}$.

\section{What role for the regions in $M L G$ ?}

The prominence of the concept of MLG and its operational significance has been underlined by the latest publication of the 'White Paper of the Committee of the Regions (CoR) on Multilevel Governance'46 in June 2009. In the document the CoR considers multi-level governance to mean coordinated action by the European Union, the Member States and local and regional authorities, based on partnership and aimed at drawing up and implementing EU policies. It leads to responsibility being shared between the different tiers of government concerned and is underpinned by all sources of democratic legitimacy and the representative nature of the different players involved.

MLG theory draws attention to the fact that due to its proximity to citizens and sensitivity to local needs, subnational scale is best suited with re-

${ }^{43}$ KOHLER-KOCH, B., op. cit., note 13, p. 5.

44 White Paper on European Governance, Brussels, 26 July 2001, COM(2001)428 final.

45 KOHLER-KOCH, B., EISING, R., op. cit., note 1.

46 See the full version of the White Paper at: http://www.aer.eu/main-issues/governance/ whitebook-on-multilevel-governance.html. See also: European Parliament resolution on the role of regional and local authorities in European integration (2002/2141(INI)) at: http://eur-lex. europa.eu/LexUriServ/LexUriServ.do?uri=OJ:C:2004:038E:0167:0171:EN:PDF 
sources to design, implement and monitor policies which are decided at supranational level ${ }^{47}$. Consequently, the regions are included in the policy channels and bound together in supranational networks by resource interdependencies. These are the key variable in shaping the outcomes of adaptation to MLG since they set the chessboard where social and economic, private and public interests maneuver for advantage ${ }^{48}$. Moreover, the regions use lobbying strategies and seek to form alliances with the EC to strengthen their role as legitimate interlocutors and exert certain pressures on state executives to obtain access to the different phases of European policy-making. If their claims are considered legitimate by the national actors, new forms of multi-level cooperation might either acquire character of consistent practices embedded over time, or might be formally institutionalized within the national legal framework. Apart from the vertical dimension of MLG, an important horizontal dynamics takes place alongside. Subnational governments constantly cooperate among themselves or with public and private sector institutions at interregional level or in transnational regional platforms. Moreover, and what is often omitted by the researchers, the executive-legislative relations in lower-level governments are crucial for subnational policy coordination and effective designing and implementation of EU directives.

With regard to subnational level, MLG should reinforce responsibilities of local and regional authorities at the national level and encourage their participation in the coordination of European policy, in this way helping to design and implement Community policies. For this, the 'White Paper' recommends that each major EU strategic reform should be accompanied by a 'regional action plan' agreed between the EC and the CoR, setting out the political mechanisms to facilitate the ownership, implementation and evaluation of the policies adopted, and including a decentralized communication plan. Moreover, the White Paper proposes to extend the open method of coordination to include regional and local authorities as well as to make 'territorial impact assessment' a standard practice.

The necessity to include regional and local tier in European MLG has been underlined not only by the CoR - the strongest regional and local lobby in Europe, but also by the European Parliament in its latest resolution on 'Good governance and EU regional policy' adopted in December 2010 considering MLG a precondition for achieving territorial cohesion in Europe and calling for its application to be made compulsory for member states in policy areas with a strong territorial impact in order to en-

\footnotetext{
${ }^{47}$ HOOGHE, L., MARKS, G., op. cit., note 26.

48 BOROŃSKA-HRYNIEWIECKA, K., op. cit., note 40.
} 
sure balanced territorial development in line with the subsidiarity principle. ${ }^{49}$

Although largely authorized by the EU itself, the measures contributing to regional participation in EU policy-making, are still weakly institutionalized and not always implemented in national contexts, or at least not in the same manner. So far, although the regions enjoy certain channels of participation in EU decision-making the extent of their influence on policy decisions is hard to measure. Moreover, the source of confusion lies in the fact, that recognition of the regional role in the EU, in spite of being acknowledged in the Treaties, needs to be accepted by the state and in this respect, empirical studies bring various records.

\section{How to 'measure' multi-level governance?}

Having characterized theoretical puzzles of MLG we might then agree with Marks that the essence of MLG is that of a system of continuous coordination and negotiations among supranational, national, regional and local jurisdictions enmeshed in territorially overreaching policy-networks ${ }^{50}$. In the horizontal actor-oriented perspective, MLG embraces state as well as non-state actors of public and private sector. It would thus appear that in order to test whether a given policy-making process is an instance of MLG or not, it would need to be checked if:

1) different levels of government are simultaneously involved in policy-making

2) non-state actors are also involved in the process

3) subnational actors operate at supranational level crossing the 'domestic-foreign' gate

4) relations between the actors take form of non-hierarchical networks ${ }^{51}$.

These are obviously only the main formal conditions for MLG described in the pioneering studies on the subject which do not take into account the whole range of practical indicators or extra, nation-specific criteria (i.e. various provisions for the regions in decentralised and non-de-

49 European Parliament resolution of on good governance with regard to the EU regional Policy: procedures of assistance and control by the European Commission, 14 December 2010, (A7-0280/2010). Full text available at: http://www.europarl.europa.eu/sides/getDoc. do? type $=$ TA\&reference $=$ P7-TA-0100468\&language $=E N \&$ ring $=$ A7-2010-0280, $($ Accessed 11.01.2010).

50 MARKS, G., op. cit. note, pp. 392-403.

${ }^{51}$ Compare: PIATTONI, S., op. cit., note 25, p. 17. 
centralised states). These conditions might thus serve as a «litmus paper» for detecting the general changes towards MLG arrangements in the EU. However, in order to provide more comprehensive and comparative data, they should be tested in conjuction with a series of systematic indicators of MLG in particular policy fields or various national contexts (i.e. in crosssectoral or cross-country comparison). To 'measure' MLG in real life - in terms of its operationalization and quality - it would need to be tested in what ways the actors or institutions involved in governance (according to the four main conditions for MLG) perform their actions in the interdependent environment. Of interest here would be not so much the policy output of governance, yet this might also be the case, but the nature of interactions among actors; the way in which policy decisions are arrived at in practice and the degree of institutionalization of 'shared governance' 52 .

On the basis of the working definition of MLG provided in the aforementioned 'White Paper on MLG' of the Committee of the Regions, a set of principles and best practices of can be extracted which might serve as a starting point to develop a less procedural and more quality-oriented analysis of multi-level and multi-stakeholder performance in different fields of European policy. And so, the overall principles of MLG deriving from the White Paper are: participation, representation, partnership, subsidiarity, proportionality, proximity, solidairity and mutual loyalty. These are the underlying general features of (effective) MLG which need to be operationalized in particular sectoral or national contexts.

Obviously, each of these principles is dependent on different corresponding qualitities of governance such as for example: access to information, social trust, institutional efficiency, transparency or accountability. There are also various instruments elaborated at the European level which serve to apply the aforementioned principles in the policy-making process such as: consultations with the CoR, subsidiarity checks, territorial impact assessments, Territorial Dialogue or European Groupings of Territorial Cooperation. In order to determine the quality (efficiency) of MLG, a researcher should therefore take into account a wide range of normative, systemic and procedural indicators applicable for a given policy area and 'test' them against the real-life mechanisms in operation (e.g. the right of regional and local governments to be consulted when decisions affecting their competences are taken; availability of channels for subnational participation in policy-making; effectiveness of information flow; quantity and quality of multi-actor partnerships,

52 In this sense, Izdebski (note 10) differentiates between studies on New Public Management focused on the outputs (outcomes) of policies, and those on public governance investigating interactions among different organizations and stakeholders acting to achieve certain goals. 
presence or absence of subsidiarity/proportionality checks or impact assessements procedures, etc). The process of 'measuring MLG' should be focused on at least two phases of the subnational involvement in EU decision-making, i.e.: the ascendant (pre-legislative and legislative) phase of policy elaboration and descendant (post-legislative) phase of policy implementation. Moreover, the analysis should cover both the vertical (i.e. local and regional authorities - national government - the EU) and horizontal (i.e. local and regional authorities - civil society) dynamics of the relations between the EU and the subnational actors. It could start from the EU level by establishing what kind of provisions there are for subnational authorities (provided by the Treaties or regulations) and what is the 'state of play' of their practical application in the investigated policy field or national context.

In the multi-level European polity, the questions of how the 'subnational scale' relates to other scales and how it can enter into the European policymaking process are first addressed at EU-level. In spite of the fact that application of MLG must be carried out with the consent of the member states and within their national legal framework, it is triggered by supranational institutions of the EU - i.e. Commission and Parliament - who act as some kind of an 'integrated conscience' challenging national governments by requiring modification and adjustment of their institutional administrative structures in a way that they correspond to the needs of cooperation and development within the EU. The EU is an attractive locus of opportunities for up-grading political influence by providing access to decision-making and the resources improving the action capacity. EU institutions are policy-making hubs from which decisions affecting regions come either in from primary (the forming treaties) or secondary (directives, decisions, green and white papers, etc.) law. Moreover, it lies in the interest of the EU to address the problem of the democratic deficit at the regional and local levels since some $80 \%$ of EU programs and policies are managed and implemented by regional and local authorities. Therefore, cooperation with the regional scale based on information exchange, expertise and policy projects leads to readiness of regions to take responsibility for certain, sometimes unsuccessful political and administrative decisions in which they were involved and to reduce possible failures in implementation. This way, the regions not only carry out strategies aimed at maximizing their influence, but they also act as stabilizing agents who take part in redefining and restructuring political space of the EU.

\section{Policy control: the case of subsidiarity monitoring}

One of the illustrations of the attempt to operationalize MLG might be the subsidiarity monitoring case. Respect for the principle of subsidiarity 
and MLG are indisociable: the former indicates the responsibilities of the different tiers of government, whilst the latter emphasizes their interaction. Subsidiarity is interpreted as a device for managing competing claims for the assignment of competences between different tiers of jurisdiction when the competence is deemed to be shared across different levels of governance. It involves consideration of both political principles as well as matters of comparative efficiency in executing policies. The appropriateness of carrying out certain policies at a particular territorial level can only be assessed in the light of the ultimate outcomes produced as a result of the assignment rule, including all possible costs (i.e. economic or political) arising from its application and the procedures used in executing that rule - i.e. in assigning policy ${ }^{53}$.

The 'Protocol on application of the principles of subsidiarity and proportionality'(PPSP) annexed to the Lisbon Treaty establishes an instrument known as the «early warning system» (EWS) which envisages increased participation of regional parliaments with legislative powers in the scrutiny of EU legislative acts regarding their compliance with the principle of subsidiarity and proportionality. The PPSP specifies that any national Parliament or any chamber of a national Parliament may, within eight weeks from the date of transmission of a draft legislative act, send to the Presidents of the European Parliament, the Council and the Commission a reasoned opinion stating why it considers that the draft in question does not comply with the principle of subsidiarity. It will be for each national Parliament or each chamber of a national Parliament to consult, where appropriate, regional parliaments with legislative powers (art. 6). According to the EWS if 'reasoned opinions' are submitted by at least a simple majority of the votes allocated to national parliaments, the proposal must be reviewed at the EU level [art. 7(3) PPSP] ${ }^{54}$. This formal requirement of a revision poses a significant innovation in the subsidiarity compliance mechanisms. The direct indication of regional legislative assemblies is a significant in-

53 BURROWS, N., CARTER, C., SCOTT, A., Subsidiarity and the Draft Treaty, Discussion Paper for SubRosa, Brussels, 2004.

54 Depending on the number of negative opinions, the Treaty provides two mechanisms as set out in Article 7 of the Protocol - the so called 'yellow card' and 'orange card'. Where the number of negative opinions from national parliaments represents at least one third of all the votes allocated to them (or one quarter for proposals in the area of judicial cooperation in criminal matters and police cooperation), the 'yellow card' mechanism applies. Under the ordinary legislative procedure, where the number of negative opinions represents a simple majority, the 'orange card' mechanism applies. Both mechanisms foresee a review of the draft legislation and may lead to amendment or withdrawal of the proposal. The 'orange card' also involves the possibility for either the European Parliament or Council to stop the legislative procedure. 
novation, the more so because it doesn't leave it up to the discretion of the member states (as it was the case in the Maastricht Treaty) to facilitate regional involvement in control of EU legislative process. In parallel with the EWS, regional authorities can conduct subsidiarity checks independently of national assemblies, through the Subsidiarity Monitoring Network of the Committee of the Regions which carries out subsidiarity monitoring activities since $2005^{55}$.

As regards the effective application of this MLG principle, the analysis of subnational involvement in the monitoring of subsidiarity to the date ${ }^{56}$ shows that it requires considerable institutional adjustment entailing incomparably more effort than bringing benefits in terms of the potential regional influence on EU policy-making process. Given the quantity of legislative projects issued by the EU every year as well as brevity of scrutiny periods (eight weeks for national parliaments and four weeks for regional assemblies) the EWS poses a big challenge for both national and regional administrations. Quite often neither regional parliaments, nor governments know in advance what will be sent to them or what policy areas they will have to analyze. Moreover, participation in the EWS requires investing time, expertise and personnel in political scrutiny of multitude of EU legislative acts which applicability will ultimately be decided by the Member States in voting at supranational level. And what interests the regional assemblies is precisely to influence state's position in a way that the national chamber presents a reasoned opinion on subsidiarity and proportionality taking into account the regional stance. For this, an efficient interparlamentary cooperation is essential, both in its horizontal (i.e. among regional parliaments of different Member States) as well as vertical dimension (i.e. between parliamentary chambers of the same member state). This issue is particularly important in the countries such as Austria, Belgium, Germany, Italy, Portugal, Spain and the United Kingdom.

To enhance multi-level cooperation on subsidiarity the mutual use of the tools of electronic communication such as interactive websites accessible at all the levels and by all actors involved in the EWS is essential. Moreover, it is crucial to establish direct access of regional assemblies to the Interparliamentary EU Information Exchange System IPEX coordinated

55 SMN was created in 2005. Its present membership is 111 partners. It operates through an interactive website http://subsidiarity.cor.europa.eu

${ }^{56}$ Evidence gathered during research stay at the SMN of the CoR in January-April 2011. More info in: VARA ARRIBAS, G., BOURDIN, D., The role of regional parliaments in the process of subsidiarity analysis within the early warning system of the Lisbon Treaty, European Institute of Public Administration (EIPA) and European Center for the Regions (ECR), 2011 . 
by the European Parliament and national chambers. One of the priorities of the CoR's Subsidiarity Monitoring Network is to set up an equivalent of IPEX (REGPEX) serving as an information exchange platform for regional assemblies. Finally, in the countries where regional parliaments have legislative powers - it is up to a given Member State to determine the domestic procedure in such a way that the reasonable opinion through the EWS could be provided within eight weeks.

The first year of using the EWS shows that it is more of a virtual mechanism than a real MLG tool. The existing forms of cooperation are either too weak or poorly used to be effective. Only $59 \%$ of the scrutiny processes initiated at the national level were completed on time within the eight-week period $^{57}$ and only eight national chambers completed their procedures in all cases for which they initiated the subsidiarity control. So far, no «yellow» or «orange card» procedure have been initiated at the supranational level.

Beyond the EWS, probably the most significant development concerning the regional involvement in subsidiarity monitoring has been granting the CoR the right to bring legal actions before CJEU on the basis of subsidiarity breach. According to the Lisbon Treaty provisions it might happen in two distinct cases: firstly, to protect the CoR's own institutional prerogatives, and secondly, to request the annulment of EU legislative acts that it considers being in breach of the principle of subsidiarity. Despite this progress, regions with legislative powers have been disappointed with the fact of not having been granted the right to appeal directly to the CJEU, but of having to use intermediary in order to defend their legislative prerogatives. On the other hand, the real and systematic involvement of the regional parliaments in the control of the early stage of European law-making process and taking their views into account could obviate the need for cases to be brought before the CJEU for infringements of the subsidiarity principle. ${ }^{58}$

The extent to which the regions with legislative power, next to the national parliaments, will be able to act as watchdogs of subsidiarity in the legislative process of the EU depends on the readiness of the national assemblies to act as intermediaries and cooperate with regional parliaments by channeling their opinions to the EU level. Considering that in some cases - i.e. Spain - the competitive nature of the domestic intergovernmental relations does not facilitate exchange of information and favors the gate-

${ }^{57}$ KACZYŃSKI, P., «Paper tigers or sleeping beauties? National Parliaments in the postLisbon European Political System», CEPS Special Report, 2011.

58 Opinion of the Committee of the Regions on Guidelines for the application and monitoring of the subsidiarity and proportionality principles, at: http://eur-lex.europa.eu/LexUriServ/ LexUriServ.do?uri=OJ:C:2006:115:0035:0041:EN:PDF 
keeping position of the state, it is only a matter of good faith that national parliaments will ensure compliance with the EWS requirements and accept that the roles of regional and national levels are efficient only when they are carried out in a concurrent, not competing way. However, the will and commitment of national assemblies will not suffice. Regional authorities need to strengthen their own administrative capacities and enhnce their 'European sensibility' for the systematic participation in the EWS.

\section{Consultation and impact assessment as instruments of $M L G$}

Another indicator for measuring the MLG might be the quantity and quality of consultation procedures conducted by the European Commission with the CoR and regional and local partners. Since 2002 steps have been taken to develop the reinforced culture of consultation called for in the White Paper on European Governance, which recognised that investment in good consultation 'upstream' may produce better legislation which is adopted more rapidly and easier to apply and enforce. The dialogue that takes place between the European Commission and stakeholders prior to the presentation of proposals and the adoption of political initiatives can take several different forms such as the mandatory consultation on key policy areas of regional concern with the $\mathrm{CoR}$ as the institutional representative of local and regional authorities ${ }^{59}$; mechanisms for sectoral consultation, which take account of the specific conditions for EU intervention in its various policy fields or the structured dialogue with the associations representing local and regional authorities. Consultation is a key element to increasing the participation of local and regional authorities in the decision making process, and is therefore seen as an essential element of MLG. Moreover, consultation ensures a higher degree of responsibility in the implementation of policy and legislation, insofar as it helps enhance the 'ownership' of such policies and legislation on behalf of the local and regional authorities, which have been consulted in the process of their conception.

Consultation procedures of the Commission are directly linked with the participation of local and regional authorities in territorial impacts assessments of the Commission. According to the aforementioned Protocole on Subsidiarity annexed to the Lisbon Treaty, Commission presents its legislative proposal to national and regional levels in the form of a a detailed statement (impact assessment) making it possible to appraise compliance

${ }^{59}$ List of consultations carried out by the CoR can be viewed at the CoR's website: http://www.cor.europa.eu/pages/CoRAtWorkTemplate.aspx?id=2286a583-ee8d-48d7-a282ba99dbbeb2da, accessed 12.06.2011 
with the principles of subsidiarity and proportionality as well as the assessment of the proposal's financial impact and, in the case of a directive, of its implications for the rules to be put in place by Member States, including, where necessary, the regional legislation. (...) Draft legislative acts shall take account of the need for any burden, whether financial or administrative, falling upon the Union, national governments, regional or local authorities, economic operators and citizens, to be minimized and commensurate with the objective to be achieved (art. 5 PPSP).

While the European Commission carry out impact assessments of its future initiatives, the $\mathrm{CoR}$ is offering its support to this process, by providing a direct access to quantitative and qualitative data from the subnational field. In 2009, the CoR and the EC launched their official cooperation on Impact assessments. As a first step a pilot test was launched by the Subsidiarity Monitoring Network on 6 February 2009 in connection with a Commission's initiative on the reduction of health inequalities. 60 So far (June 2011) five impact assessments have been conducted through the $\mathrm{CoR}^{61}$ reflecting a technical input from the local and regional stakeholders' point of view, and constitute a valuable source of information for CoR members as well as for EU policy-makers and other external stakeholders. Impact assessments are a crucial tool for achieving a better regulation and regulatory environment, through the added value of specific local and regional points of view. They should help to avoid conflicts regarding compliance with the subsidiarity principle at a very early stage in the pre-legislative process as well as to detect all significant implications of the proposed legislation for the ultimate receivers and implementers of the acquis communautaire.

A researcher wanting to test the practical application of MLG in prticular policy fields should take into account questions about the absence or presence of consultative procedures and impact assessement analysis as well as the qualitative and quantitative aspect of subnational input in their elaborations.

${ }^{60}$ The second pilot test was launched concerning a future Directive on the quality of water intended for human consumption replacing council directive 98/83/EC at the end of October 2009. 93 replies were received and processed into a final report which was officially transmitted to the EC. In 2010, the CoR launched a consultation on the territorial impacts of the EU post-2010 Biodiversity Strategy. The consultation was conducted through the following CoR platforms: the SMN, the EU2020 Platform and the EGTC Expert Group. It ran from 9 September to 5 November 2010 and received sixteen contributions from local and regional authorities. All contributions together with a report on the consultation were sent to the European Commission on 10 November 2010.

${ }_{61}$ The full list of IAs can be found on: http://portal.cor.europa.eu/subsidiarity/Pages/ ImpactAssessmentConsultations.aspx, accessed 2.06.2011 


\section{Regional involvement in cohesion policy: the case of EGTC}

One of the best illustrations of mechanisms of MLG is obviously EU cohesion policy ${ }^{62}$. The institutionalization of 'partnership' principle in managing EU cohesion policy should be considered as an example of MLG in the sense of making the region more capable of contributing to policy-making process by shaping and designing its own development strategies. Partnership became a powerful tool for the EC to break-open the two-level relations with the Member States and change them into multi-level relations including subnational and local authorities ${ }^{63}$. The subsequent reforms of Structural Funds extended the principle of partnership to economic and social actors causing that cohesion policy has acquired a character of policynetworks (one of the principle features of MLG) in which state, non-state, public and private interests merge in elaboration of best ways and means to make use of EU financial resources.

In the last years transnational and cross-border cooperation have become a priority for the EU as means to promote economic development, social cohesion, and cross-border integration of the regions. In 2006 the European Commission issued a Regulation No 1082 setting up an innovative cooperation instrument to be applied by the Member States for the management of the Structural Funds called the European Grouping of Territorial Cooperation (EGTC). It is a new legal instrument designed to facilitate and promote cross-border, transnational and interregional cooperation.

The EGTC is unique in the sense that it enables public authorities of various member states to team up and deliver joint services, without requiring a prior international agreement to be signed and ratified by national parliaments. It gives the possibility of involving different institutional levels and actors (i.e. Member States, regional and local authorities, bodies governed by public law or associations consisting of such bodies) in a single cooperative structure thus opening up the prospect of new forms of MLG. Moreover, as the instrument is endowed with decision-making powers, it is capable of gaining a highly visible profile in the areas concerned. It also takes account of the problems of administrative asymmetry between Member States and creates a legally recognized platform for the co-ordination and clearance of related issues between the relevant players from different administrative tiers.

62 PIATTONI, S., op. cit., note 25, HOOGHE, L., MARKS, G., op. cit., note 1; JEFFERY, $\mathrm{CH}$., «Sub-national mobilization and European integration: does it make any difference?», in Journal of Common Market Studies 38, no. 1: 1-23, 2000.

${ }^{63}$ HOOGHE, L., MARKS, G., op. cit., note 1, p. 84. 
According to the CoR, EGTCs demonstrate both the political will and commitment to institutionalize and further develop new and existing cooperation experience and serve as laboratories of MLG ${ }^{64}$. One of the most important principles of MLG listed in the CoR's White Paper has been the 'proximity' and 'participation'. These two are well applied within the framework of EGTC which promotes the so called 'integrated and territorial approach' to policies. The former should ensure that each policy sector is developed not in isolation but in the context of a coherent vision for the socio-economic development of EU territories which calls for a deeper integration of public policies with territorial impact, in particular with regard to the economic, social and environmental sphere. Consequently, at the regional level, EGTCs are requested to entwine partnerships for Structural Funds with other economic and social networks (the horizontal dimension of MLG). The latter entails that EGTCs have the right size, the necessary political commitment, the resources and last but not least the know-how to develop territorial strategies, based on effective needs assessment leading to locally responsive outputs.

In terms of institutional contexts for setting up EGTCs, the empirical evidence gathered in the CoR's study on EGTC indicates that they are more easily implemented in areas previously participating in the Community Initiative INTERREG which strengthened horizontal and vertical cooperation record in various regions and created the ground for the set-up of stronger cooperation instruments. In various cases INTERREG programmes created a template for statutes and conventions and for achieving a general agreement on the future objectives of the EGTC $^{65}$.

\section{MLG and regional empowerment}

The role of subnational authorities in EU policy-making and whether European integration empowers or disempowers their autonomy conform sub-issues of MLG debate ${ }^{66}$. It is widely accepted in the institutionalist lit-

${ }^{64}$ See the study «The European Grouping of Territorial Cooperation (EGTC): state of play and perspectives» elaborated by the Committee of the Regions, June 2008. Available at: http://www.pouvoirs-locaux-francais.eu/upload/dossiers/20080701123542_EGTC_Draft_ Report_090608_CdR.pdf

${ }^{65}$ For more information on EGTC see: http://portal.cor.europa.eu/egtc/en-US/Pages/ welcome.aspx

${ }^{66}$ MORATA, F., op. cit., note 1; BOURNE, A. The European Union and the accommodation of Basque difference in Spain, Manchaster University Press, 2008.; BÓRZEL, T., op. cit., note1; KEATING, M., The New Regionalism in Western Europe, Territorial Restructuring and Political Change, Cheltenham, Edward Elgar, 1998; JEFFERY, C., «Regional Informa- 
erature, that any institutional change empowers some actors over others ${ }^{67}$. In this sense, the greater the scope of regional autonomy, the stronger the regional power understood as the ability of regional authorities to influence public policy decision in their favor and their ability to control, or escape the control, of other political actors ${ }^{68}$. Consequently, equipping the regions with new possibilities of influencing EU decisions might imply reducing the influence capacity of other actors involved in governance. However, as some authors notice, it is difficult to assess with any precision the degree to which increased regional mobilization and participation in EU policy-making translates into de-facto regional empowerment ${ }^{69}$.

In the context of MLG, regional empowerment can be defined as the increased capacity of subnational authorities to influence European policymaking through their involvement in decision-making process which ideally should translate into co-responsibility for governance, awareness of its costs and increase in its effectiveness. In reality, the existence of conflicting interests among actors involved in governance inhibits the shift of empowerment.

It has to be pointed out that regional empowerment through MLG might have different origins. It might derive from the greater availability of relational resources such as facilitating political situation and support of a particular ruling party or interest group (political empowerment) or facilitating institutional culture and access to ideological, symbolic, informational resources (ideational empowerment) ${ }^{70}$. Another way of understanding empowerment is through an extended and facilitated cooperation and alliances with institutional actors situated at multiple levels of the EU, or with similar authorities through means of transnational regionalism (coalitional empowerment). Further, empowerment can also be achieved by improved policy performance triggered by exposure to 'good practices' circulating in the EU (administrative empowerment ${ }^{71}$. Sometimes greater influence capacity

tion Offices in Brussels and Multi-Level Governance in the EU: A UK German Comparison», in Regional and Federal Studies, Vol.6, No.2, 1996, pp. 183-203; JEFFERY,C., «Subnational mobilization and European integration: does it make any difference?», in Journal of Common Market Studies 38, No. 1, 2000, pp. 1-23.

${ }^{67}$ BÖRZEL, T. op. cit., note 1; MARSH, D., STOKER, G.; Teorie i metody w naukach politycznych, Kraków: Wydawnictwo Uniwersytetu Jagiellońskiego, 2006.

${ }^{68}$ Some of the sources of regional power are legal-constitutional standing, financial resources, relational resources directly linked with access to strategic decision-making bodies or symbolic resources.

69 BOURNE, A. K, «The impact of European integration on regional power», in Journal of Common Market Studies 41, no. 4, 2003, pp. 597-620.

${ }^{70}$ KURTZ, D., Political Anthropology, Westview Press, 2001.

${ }^{71}$ PIATTONI, S., op. cit., note 25. 
may derive from direct participation in the policy-making, which is the essence of MLG (policy empowerment). It might happen either at the ascendant shaping phase of EU policy or at the descendant, implementation phase. EU cohesion policy provides examples of regional policy empowerment in the ascendant phase of EU policy-making, i.e. at the stage of structural programming and creation of operational programs. Yet, it is in the implementation rather than elaboration phase that such type of empowerment is mostly gained ${ }^{72}$. From the functional and normative point of view, the most important kind of empowerment, which decides about the legitimization of the real regional involvement in the European governance derives from changes in formal powers of subnational authorities resulting from constitutional, statutory or other reforms based on transferring more competences to regional authorities (institutional empowerment). This is however a long and incremental process of institutional change and rarely depends on the resources situated at the subnational level.

The empirical findings suggest that operationalization of MLG provides various opportunities but also poses constraints for the region. As regards the opportunities: MLG entails the regional ability to access information and resources for decision-making, to cooperate with other actors, to learn and access skills for improving policy performance as well as the ability to create a positive self-image or to overcome certain stigma. Multi-level coordination of policy implementation helps to economize on resources such as information, expertise and personnel. It surely increases the freedom of subnational actors to connect with supranational authorities without the permission of the national state. It also extends and facilitates participation in transnational networks of cooperation (fourth condition of MLG) with other regions with common policy problems or qualified in the same financial objectives.

Yet, although MLG provides the regions with new possibilities of policy contribution or policy control, it does not bring about significant redefinition of the institutional, let al.one 'constitutional domestic set-ups' to the extent that the regions are granted new legal competences in EU decisionmaking. Creation of regional policy networks and enhancement of vertical intergovernmental coordination are only side effects of the partnership principle and do not legally empower regional actors. In this regard, the 'White Paper on MLG' stresses that MLG is not a legal instrument meant to alter the division of powers, but a dynamic process of horizontal and vertical dimension which represents a political blueprint for all the involved actors. Moreover, the empirical studies reveal that MLG in policy implementa-

72 HOOGHE, L., MARKS, G., op. cit. note 1. 
tion might also pose institutional burden for the region, especially in terms of coordinating transposition with local level institutions which in various cases is far from perfect ${ }^{73}$. Mobilizing additional resources to implement EU legislation might actually disempower subnational administrations in a sense that they might have to shift their administrative effort away from other important social issues or encounter administrative delays. On the other hand, multi-level transposition entails that potential implementation failures are likely to meet with financial punishments of the responsible regional authorities (as in the case of Spain). There is also little evidence that transnational regional networks of cooperation enhance regional influence on EU policy process. Regional involvement in activities of networks of legislative regions surely assumes a legitimizing and controlling function in the sense that it strengthens the regional capacity to liaise with EU institutions and to transform policy-making process into more inclusive and open for scrutiny. However, this 'power to transform' should not be confused with the 'power to decide' still concentrated in the intergovernmental circles of national interests represented in the Council of the $\mathrm{EU}^{74}$.

\section{Conclusions: Where do we go from here?}

Studying the evolution of the regional issue salience in the EU leads to the conclusion that the new institutional solutions delivered by the subsequent EU treaties and regulations are meant to enhance the mechanisms of MLG based on cooperation and resource exchange between European, national and subnational authorities. These provisions, at least at first glance, seem to result in stronger interdependence of the various tiers of governance rather than in reinforcement of the regions as independent players vis$a$-vis the national governments. Moreover, although new vectors of power and forms of subnational engagement with the EU have arisen, the postulates and conditions for an effective MLG with the regions have not yet been met in full. In other words, the symptoms of operationalization of MLG have not yet translated into systemic effects.

The degree of empowerment which the region obtains from MLG seems to depend on the EU's perception of regions' 'utility' as authoritative decision-makers. In this sense, the opportunities for empowerment are

${ }^{73}$ Compare: MILIO, S., From policy to policy implementation in the European Union. The challenges of a multi-level governance system, Tauris Academic Studies, 2010.

${ }^{74}$ Based on the findings gathered in the unpublished doctoral thesis of BOROŃSKAHRYNIEWIECKA, K., Participation of the Basque Autonomous Community in European policy-making: evolution towards multi-level governance?, University of Wrocław 2011. 
usually based on the pragmatic premises of the EU which sees increased regional involvement as means to achieve better effectiveness of implementation, democratic legitimization and co-responsibility for policy failures. The EU turns to means of MLG to redress its own 'delivery deficit' due to the gap between what is formally decided by the national and supranational powers and what is actually delivered in the regional world of practice. For this, the EU sets region-friendly guidelines which challenge the gatekeeping power of the nation states. The examples of the EWS or EGTC illustrate this case.

The reasons of constraints are twofold: Firstly, they are inbred in the very nature of MLG which draws more on resources, capacities and strategies of the regions as active input-givers and favours the stronger ones which are able to operationalize resources and separate policy-oriented actions from the destructive influence of politics. The latter is often very difficult to achieve in the real life, especially in the situation of strong socio-political cleavages. Secondly, the constraints derive from political reluctance of the main EU policy-makers towards redefinition of the institutional setting which would equip the regions with new institutional decision-making powers. The motives behind this are based on concerns that an increased number of stakeholders might complicate the EU policy-making process already constrained by the conflicting interests of the twenty seven member states. In this sense, enhanced MLG mechanisms are challenged by their opponents who fear dragging the EU towards a systemic deadlock through a 'joint decision trap' 75 .

While it may be unfashionable to say so, the national scale remains the most important point of reference in EU evolving multi-level polity. The principle of participation crucially depends on central governments following an inclusive approach when developing and implementing EU policies. For this reason, while studying MLG in various national contexts, the empirical determination of the regional participation in EU policy-making entails answering some more detailed questions regarding the bundle of national-specific conditions of its domestic environment, such for example: the region's formal and legal status within the state constitutional and administrative system taking into account the financial autonomy to allocate crucial resources, the de facto degree of regional and local autonomy in relation to European affairs as well as the capacities and limits to subnational participation in EU bodies established within the domestic institutional framework.

75 Compare: SCHARPF, F. W., «The Joint-Decision Trap. Lessons From German Federalism and European Integration» in Public Administration, Vol. 66, No. 2., 1998, pp. 239-78. 
On the other hand, the policy-oriented approach to MLG should take into account the fact that different policy areas are subject to different policy-making patterns. Moreover, MLG does not apply to all EU policies, and when it does, it rarely applies symmetrically or homogeneously. For this reason, the applicability of MLG principles and indicators should be assessed carefully and its links with political mobilization, institutional change and policy involvement in a particular context should be analyzed as precisely as possible. The policy-oriented effect of MLG is one of the most underresearched issues in the governance studies. The literature still lacks in-depth case studies of subnational role in policy shaping phase, especially in cases of policies with high territorial impact such as environment or sustainable development and innovation. It therefore offers an interesting field for investigation to see to what extent policy designs are aligned with policy delivery to produce locally responsive outputs. Such policy 'quality testing' at subnational level could help to establish not only which patterns contribute to regional empowerment but also to enhancing joint responsibility for EU governance as an answer to EU democratic deficit and - more importantly - to the current economic crisis which has entailed the need for a coordinated action of the various levels of government. 